\title{
RESIDUES OF ENROFLOXACIN AND ITS MAIN METABOLITE CIPROFLOXACIN IN BROILER CHICKENS
}

\author{
PETROVIĆ JELENA*, BALTIĆ $M^{\star * *}$, ĆUPIĆ $\mathrm{V}^{* *}$, STEFANOVIĆ $\mathrm{S}^{* * *}$ and STOJANOVIĆ DRAGICA* \\ *Scientific Veterinary Institute "Novi Sad", Novi Sad; **Faculty of Veterinary Medicine, Belgrade; \\ $* * \star$ Institute of Meat Hygiene and Technology, Belgrade \\ (Received 1. May 2006)
}

The presence of enrofloxacin residues in muscle and liver after peroral administration of enrofloxacin (10 $\mathrm{mg} / \mathrm{kg}$ bw/day) to chickens was studied. Microbiological method - plate pH 8.0 with Escherichia coli NCIMB 11595 and HPLC with fluorescence detection were used for the detection of enrofloxacin residues. During the 5 days dosing period, enrofloxacin concentrations in breast muscle and liver greatly exceeded the EU MRL values. Ciprofloxacin was not detected in muscles after 2 days of dosing, but it was detected in the liver in concentrations over the MRL. During the post treatment period, enrofloxacin and ciprofloxacin concentrations in the breast muscle and liver exceeded the MRL values until the $4^{\text {th }}$ day of the withdrawal period. Ciprofloxacin was not detected in the breast muscle after 4 days post dosing, but it was detected in the liver at concentrations below MRL. Four days withdrawal period is the allowed time for the drug concentration to descrease to an acceptable level in the meat and liver, prior to slaughter (below MRL). Microbiological method - plate $\mathrm{pH} 8.0$ with Escherichia coli NCIMB 11595 gave positive results in all the samples which had residues above MRL values.

Key words: chickens, enrofloxacin, HPLC, microbiological method, residues

\section{INTRODUCTION}

Enrofloxacin is an antimicrobial agent developed in the late 1980s exclusively for use in veterinary medicine. Enrofloxacin, $\mathrm{C}_{19} \mathrm{H}_{22} \mathrm{FN}_{3} \mathrm{O}_{3}$ or (1cyclopropyl-6-fluoro-1,4-dihidro-4oxo-7-[4-ethyl-1-piperazinyl]-3-quinoline carboxylic acid) belongs to the early second or second generation of fluoroquinolone antimicrobials, which have bactericidal activity against Enterobacteriaceae and other Gram-negative bacteria and have some activity against certain Grampositive cocci (Martindale, 2005; Martinez et al., 2005; Cupic et al., 2002). Fluoroquinolones damage bacterial DNA and lead to defects in negative supercoiling. This effect is linked to the inhibition of DNA gyrase activity, an enzyme found in all bacteria (Prescott et al., 2000). Enrofloxacin is approved for 
therapeutic and prophylactic usage in poultry in Serbia and Montenegro (Jezdimirovic, 2002). Common poultry infections, such as mycoplasmal infections, colibacillosis and pasteurellosis, frequently are treated with enrofloxacin (Report WHO, 1998; Jezdimirovic, 2002; Martinez et al., 2005).

After oral application, enrofloxacin is well absorbed, distributed into tissues and excreted in the urine and feces at high concentrations (Prescott et al., 2000; Less and Aliabadi, 2002). Enrofloxacin is metabolised in the liver to its main metabolite ciprofloxacin and some minor metabolites (EMEA, 1998). Ciprofloxacin has also a bactericidal activity, as the parent compound it is approved in human medicine.

Phototoxic skin reactions in humans (Klecak et al., 1997), chondrotoxic effects in young animals (Stahlmann et al., 2000) and tendon rupture (Pierfitte et al., 1995) can be induced by fluoroquinolone antimicrobials. Facultative anaerobic human intestinal microflora can be strongly suppressed with low levels of ciprofloxacin (Cerngila and Kotarski, 1999). Ho et al. (2003) had also reported 15 cases of allergic reactions to ciprofloxacin, some of occured after the first usage of this quinolone.

Safe food is free of residues, meaning that levels of residues in tissues is lower than MRL according to the regulations. MRL values for fluoroquinolone antimicrobials are not established in Serbia and Montenegro. MRL values for the total sum of enrofloxacin and ciprofloxacin in EU are $100 \mathrm{ng} / \mathrm{g}$ for chicken meat and $200 \mathrm{ng} / \mathrm{g}$ for the liver (Consleg, 2002).

The aim of this study was to investigate the target tissue residues of enrofloxacin and its main metabolite ciprofloxacin, according to MRL values to eliminate health risk for the consumers. Presence of enrofloxacin and ciprofloxacin in breast muscle and liver, were detected by microbial inhibition assay and by HPLC method.

\section{MATERIALS AND METHODS}

Animals

The study was performed on 65 healthy chickens (Arbor acres), 1-day old chickens were included in the experiment. At the age of two weeks chickens were randomly divided in two groups. Group A (30 animals) was the control group. This group was not treated with antibiotics. At the age of 28 days the chickens in group B (35 animals) were given daily doses of enrofloxacin (10 mg/kg bw/day) via drinking water, for five consecutive days. In our work we used Enrocin ${ }^{\circledR} 10 \%$ ad us. vet. (Hemovet - Serbia and Montenegro), $1 \mathrm{ml}$ of solution containing $100 \mathrm{mg}$ enrofloxacin.

A number of chickens was euthanized two days before starting therapy, during therapy, during the withdrawal period and after the end of the withdrawal period. At each sampling time three chickens were euthanised, and samples of breast muscle and liver were obtained. The samples were stored at $-20^{\circ} \mathrm{C}$, until assayed for presence and concentration values of enrofloxacin and ciprofloxacin. 
Acta Veterinaria (Beograd), Vol. 56. No. 5-6, 497-506, 2006.

Petrović Jelena et al.: Residues of enrofloxacin and

its main metabolite ciprofloxacin in broiler chickens

Qualitative analysis: microbiological method

Standards were purchased from Sigma Company - USA (enrofloxacin) and Bayer- Germany (ciprofloxacin). Test agar pH 8.0 was seeded with Escherichia coli NCIMB 11595. A working solution of E. coli NCIMB 11595 was made with a freshly prepared culture. The culture was diluted in peptone-salt solution to give optical density of 0.452 at $620 \mathrm{~nm}$ in a $10 \mathrm{~mm}$ cell, with the use of peptone-salt solution as a reference. Sterile Petri dishes were filled with inoculated test agar. All the plates were subjected to quality control. Paper disks containing 0.003 ciprofloxacin $\mu \mathrm{g} /$ disk (Mast Diagnostic, Mereyseyside, UK) were placed in the center of the Petri dish. Detection levels of plate pH 8.0 E. coli NCIMB 11595 were previously determined (unpublished data): $50 \mathrm{ng} / \mathrm{g}$ enrofloxacin and $25 \mathrm{ng} / \mathrm{g}$ ciprofloxacin. Meat and liver were sampled while still frozen. An $8 \mathrm{~mm}$ diameter cork borer was used to remove a cylinder of frozen meat. The meat cylinders were cut into $2 \mathrm{~mm}$ thick disks. Four disks of meat were placed on opposite ends of the plate. Each sample was examined in 12 replicates. The plates were kept refrigerated for 2 hours and then incubated on $37^{\circ} \mathrm{C}$ for $24 \mathrm{~h}$. After incubation the plates were inspected for inhibition zones around the meat disks and the average inhibition zone (IZ) for all 12 replicates was recorded $(2 \mathrm{~mm}$ width was considered as positive).

Quantitative analysis - HPLC with fluorescence detection

Methanol, acetonitrile, n-hexane, and phosphoric acid were purchased from J. T. Baker (Holland). Enrofloxacin and ciprofloxacin analytical standards were purchased from Sigma Company - USA. All the solvents were of HPLC purity.

Liquid chromatography (Ramos et al., 2003) with fluorescence detection at excitation wavelength of $280 \mathrm{~nm}$ and emission wavelength of $455 \mathrm{~nm}$ was used for the determination of enrofloxacin and ciprofloxacin residues in meat and liver. Detection limit is $10 \mathrm{ng} / \mathrm{g}$ and quantification limit is $20 \mathrm{ng} / \mathrm{g}$.

Enrofloxacin and ciprofloxacin were detected isocratically in 7 to 10 minutes. Waters "Sunfire" column, C18, $150 \times 4.6 \mathrm{~mm}, 3.5 \mu \mathrm{m}$ particle size was used for separation at a flow rate of $0.8 \mathrm{~mL} / \mathrm{min}$. The mobile phase $(0.01 \mathrm{M}$ phosphoric acid ( $\mathrm{pH}$ 3)/acetonitrile; 80:20 v/v) was used to elute both compounds. Quantification was performed using the external standard method and the results were obtained from the calibration curve of blanks fortified at four levels.

Statistical analysis

Statistical analysis was performed by Microsoft Office Excel 2000 and statistical program SPSS for Windows 8.0.0. ANOVA were analyzed by Hadžić (1992). Screening method data were analyzed by the use of descriptive statistical methods. Differences in IZ diameters were analyzed for statistical significance by the use of ANOVA and Student's t-test. Differences of $p<0.05$ were considered significant. 


\section{RESULTS}

Breast muscle and liver samples from day 1 to day 5 of dosing and from day 1 to day 22 (post dose) were analyzed by the microbiological and HPLC methods for enrofloxacin and ciprofloxacin concentrations, and the results are shown in Tables 1-5 and figures 1-2. During the 5 days dosing period, enrofloxacin concentrations in the breast muscle and liver greatly exceeded the MRL values. Ciprofloxacin was not detected in the muscles on day 2 of dosing, but it was detected in the liver in concentrations over MRL. All the muscle and liver samples during the treatment gave positive results on plate pH 8.0 E. coli NCIMB 11595.

Table 1. Determination of residues by microbiological method during enrofloxacin administration (IZ in $\mathrm{mm}$ )

\begin{tabular}{|c|c|c|c|c|c|c|c|c|}
\hline \multicolumn{2}{|c|}{$\begin{array}{c}\text { Treatment } \\
\text { day }\end{array}$} & $\bar{x}$ & SD & SE & Cv & IV & $\mathrm{t}$ & $\begin{array}{c}\% \\
\text { positive }\end{array}$ \\
\hline \multirow{2}{*}{-1} & $\bar{M}$ & 0 & - & - & - & - & \multirow[b]{2}{*}{ - } & 0.00 \\
\hline & $L$ & 0 & - & - & - & - & & 0.00 \\
\hline \multirow{2}{*}{2} & $\mathrm{M}$ & 12.62 & 1.088 & 0.272 & 8.62 & 3.00 & \multirow{2}{*}{$9.350^{*}$} & 100.00 \\
\hline & $L$ & 15.87 & 0.806 & 0.202 & 5.05 & 2.00 & & 100.00 \\
\hline \multirow{2}{*}{5} & $M$ & 13.58 & 1.349 & 0.275 & 9.93 & 5.00 & \multirow{2}{*}{$5.645^{\star}$} & 100.00 \\
\hline & $\mathrm{L}$ & 15.75 & 1.032 & 0.211 & 6.55 & 3.00 & & 100.00 \\
\hline
\end{tabular}

M - meat; L - liver; *- significant difference $(p<0.05)$

Table 2. Determination of residues by microbiological method after the end of treatment ( $\mathrm{IZ}$ in $\mathrm{mm})$

\begin{tabular}{|c|c|c|c|c|c|c|c|c|}
\hline \multicolumn{2}{|c|}{$\begin{array}{c}\text { Post treatment } \\
\text { day }\end{array}$} & $\bar{x}$ & SD & SE & Cv & IV & $\mathrm{t}$ & $\begin{array}{c}\% \\
\text { positive }\end{array}$ \\
\hline \multirow{2}{*}{1} & $\mathrm{M}$ & 15.00 & 1.461 & 0.365 & 9.74 & 4.00 & \multirow{2}{*}{$3.721^{*}$} & 100.00 \\
\hline & $L$ & 16.19 & 1.276 & 0.319 & 7.88 & 3.00 & & 100.00 \\
\hline \multirow{2}{*}{2} & $M$ & 10.46 & 0.658 & 0.134 & 6.29 & 3.00 & \multirow{2}{*}{$4.338^{*}$} & 100.00 \\
\hline & $\mathrm{L}$ & 11.96 & 1.301 & 0.266 & 10.88 & 3.00 & & 100.00 \\
\hline \multirow{2}{*}{4} & $M$ & 1.42 & - & - & - & 9.00 & \multirow[b]{2}{*}{ - } & 16.67 \\
\hline & $L$ & 8.04 & 0.955 & 0.195 & 2.42 & 3.00 & & 100.00 \\
\hline \multirow{2}{*}{6} & $M$ & 0.00 & - & - & - & - & \multirow[b]{2}{*}{ - } & 0.00 \\
\hline & $\mathrm{L}$ & 6.75 & 0.989 & 0.202 & 14.65 & 4.00 & & 100.00 \\
\hline \multirow{2}{*}{8} & $M$ & 0.00 & - & - & - & - & \multirow[b]{2}{*}{ - } & 0.00 \\
\hline & $L$ & 6.00 & 0.000 & 0.000 & 0.00 & 0.00 & & 100.00 \\
\hline \multirow{2}{*}{9} & $M$ & 0.00 & - & - & - & - & \multirow[b]{2}{*}{ - } & 0.00 \\
\hline & $\mathrm{J}$ & 6.67 & 2.099 & 0.428 & 31.48 & 5.00 & & 100.00 \\
\hline \multirow{2}{*}{11} & $M$ & 0.00 & - & - & - & - & \multirow[b]{2}{*}{ - } & 0.00 \\
\hline & $L$ & 3.75 & 0.447 & 0.112 & 11.92 & 1.00 & & 100.00 \\
\hline \multirow{2}{*}{17} & $M$ & 0.00 & - & - & - & - & & 0.00 \\
\hline & $\mathrm{L}$ & 0.00 & - & - & - & - & & 0.00 \\
\hline \multirow{2}{*}{22} & $M$ & 0.00 & - & - & - & - & \multirow{2}{*}{-} & 0.00 \\
\hline & $L$ & 0.00 & - & - & - & - & & 0.00 \\
\hline
\end{tabular}

M - meat; L - liver; *- significant difference $(p<0.05)$ 
Acta Veterinaria (Beograd), Vol. 56. No. 5-6, 497-506, 2006.

Petrović Jelena et al.: Residues of enrofloxacin and

its main metabolite ciprofloxacin in broiler chickens

Table 3. Statistical significance of differences $\mathrm{IZ}(\mathrm{mm})$ in chicken meat

\begin{tabular}{|c|c|c|c|c|}
\hline Day & $4^{\mathrm{PT}}$ & $2^{\mathrm{PT}}$ & $1^{\mathrm{PT}}$ & $5^{\mathrm{T}}$ \\
\hline \hline $2^{\mathrm{T}}$ & $2.25^{\star}$ & $10.93^{*}$ & $6.39^{\star}$ & $9.76^{\star}$ \\
\hline $5^{\mathrm{T}}$ & $2.23^{\star}$ & $10.75^{\star}$ & $15.16^{\star}$ & - \\
\hline $1^{\mathrm{PT}}$ & $11.22^{*}$ & $11.22^{*}$ & - & - \\
\hline $2^{\mathrm{PT}}$ & $12.63^{\star}$ & - & - & - \\
\hline
\end{tabular}

T - treatment day, ${ }^{P T}$ - post treatment day, ${ }^{*}$ - significant difference $(p<0.05)$

Table 4. Statistical significance of differences $I Z(\mathrm{~mm})$ in chicken liver

\begin{tabular}{|c|c|c|c|c|c|c|c|c|}
\hline Day & $11^{\mathrm{PT}}$ & $9^{\mathrm{PT}}$ & $8^{\mathrm{PT}}$ & $6^{\mathrm{PT}}$ & $4^{\mathrm{PT}}$ & $2^{\mathrm{PT}}$ & $1^{\mathrm{PT}}$ & $5^{\mathrm{T}}$ \\
\hline \hline $2^{\mathrm{T}}$ & $42.27^{\star}$ & $16.73^{\star}$ & $48.99^{\star}$ & $30.26^{\star}$ & $32.32^{\star}$ & $14.36^{\star}$ & 1.32 & 1.86 \\
\hline $5^{\mathrm{T}}$ & $47.98^{\star}$ & $18.72^{\star}$ & $46.28^{\star}$ & $31.18^{\star}$ & $36.25^{\star}$ & $8.73^{\star}$ & $2.40^{\star}$ & - \\
\hline $1^{\mathrm{PT}}$ & $29.75^{\star}$ & $21.64^{\star}$ & $31.92^{\star}$ & $20.47^{\star}$ & $32.69^{\star}$ & $10.30^{\star}$ & - & - \\
\hline $2^{\mathrm{PT}}$ & $53.03^{\star}$ & $13.18^{\star}$ & $22.43^{\star}$ & $19.35^{\star}$ & $10.05^{\star}$ & - & - & - \\
\hline $4^{\mathrm{PT}}$ & $15.29^{\star}$ & $3.48^{\star}$ & $10.48^{\star}$ & $3.95^{\star}$ & - & - & - & - \\
\hline $6^{\mathrm{PT}}$ & $10.42^{\star}$ & 0.18 & $3.81^{\star}$ & - & - & - & - & - \\
\hline $8^{\mathrm{PT}}$ & $20.12^{\star}$ & 1.56 & - & - & - & - & - & - \\
\hline $9^{\mathrm{PT}}$ & $5.85^{\star}$ & - & - & - & - & - & - & - \\
\hline
\end{tabular}

$\mathrm{T}$ - treatment day, ${ }^{\mathrm{PT}}$ - post treatment day, ${ }^{*}$ - significant difference $(p<0.05)$

Table 5. Enrofloxacin residues (ng/g) in chicken muscle and liver determined by HPLC method

\begin{tabular}{|c|c|c|c|c|}
\hline \multirow{2}{*}{ Day } & \multicolumn{2}{|c|}{ ENROFLOXACIN } & \multicolumn{2}{c|}{ CIPROFLOXACIN } \\
\cline { 2 - 5 } & meat & liver & meat & liver \\
\hline \hline-1 & 0.0 & 0.0 & 0.0 & 0.0 \\
\hline $2^{\mathrm{T}}$ & 134.4 & 507.5 & 0.0 & 187.1 \\
\hline $1^{\mathrm{PT}}$ & 577.8 & 1196.1 & 49.5 & 817.8 \\
\hline $4^{\mathrm{PT}}$ & 28.2 & 54.7 & 0.0 & 68.4 \\
\hline $6^{\mathrm{PT}}$ & 24.9 & 45.4 & 0.0 & 0.0 \\
\hline $9^{\mathrm{PT}}$ & 24.8 & 45.2 & 0.0 & 0.0 \\
\hline $22^{\mathrm{PT}}$ & 0.0 & 0.0 & 0.0 & 0.0 \\
\hline $29^{\mathrm{PT}}$ & $/$ & 0.0 & $/$ & 0.0 \\
\hline
\end{tabular}

During the post treatment period, enrofloxacin and ciprofloxacin concentrations in breast muscle and liver exceeded the MRL values until 4 days of the withdrawal period. Ciprofloxacin was not detected in the breast muscle on 4 days post dosing, however it was detected in the liver in concentrations below MRL. All muscle samples during the post treatment gave positive results on plate pH 8.0 E. coli NCIMB 11595 until day 4, on that day only $16.67 \%$ muscle samples were positive. Liver samples were $100 \%$ positive until 17 days post treatment on plate pH 8.0 E. coli NCIMB 11595. Ciprofloxacin residues were not detected by HPLC in muscle and liver samples on day 6 post treatment and after, but enrofloxacin residues were detected in these samples until 22 days post treatment. 


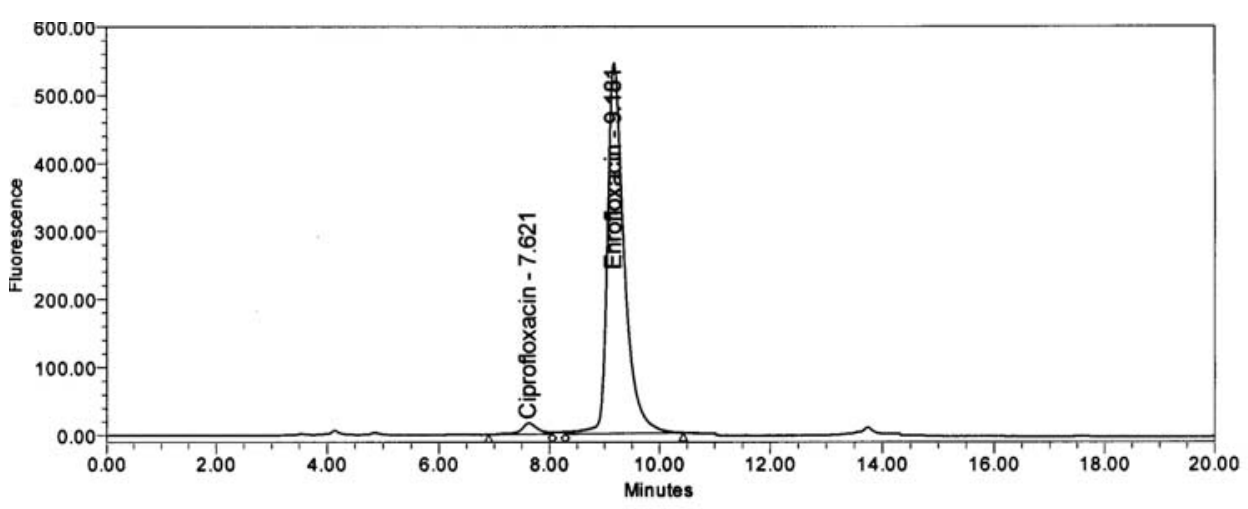

Figure 1. Chromatographic determination of enrofloxacin residues in chicken muscle - the first day of withdrawal period

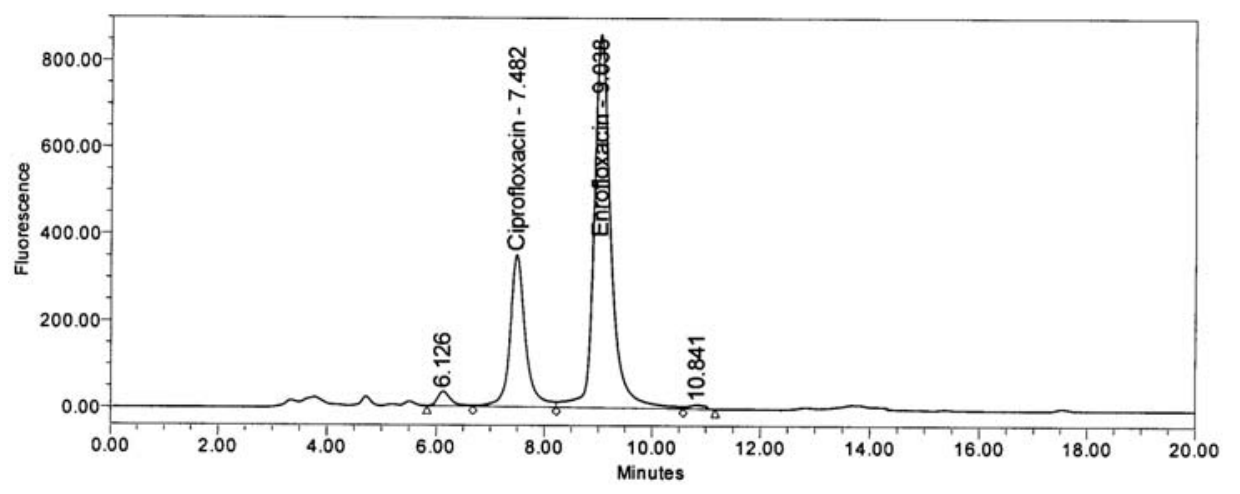

Figure 2. Chromatographic determination of enrofloxacin residues in chicken liver - the first day of withdrawal period

\section{DISCUSSION}

High concentrations of enrofloxacin in the meat and liver $24 \mathrm{~h}$ after the beginning of the treatment are a consequence of rapid absorption from chicken intestines (Prescott et al., 2000). Peak serum concentrations occur within $72 \mathrm{~h}$ (Anadon et al., 1990). Enrofloxacin is well distributed from plasma into tissues (Anadon et al., 1995) and its concentration was higher in the liver than in breast muscle in all our examinations. Enrofloxacin concentration was 3.78 times higher in the liver than in muscles $24 \mathrm{~h}$ after the beginning of treatment. This correlation slowly decreases on the first day post treatment -2.07 times and on day 4 post treatment 1.94 times. The decrease stopped after this period and correlation was equalized at 1.82 times. Similar results on distribution of enrofloxacin in the liver 
and muscle were reported by Schneider (2001), enrofloxacin concentrations were 4-4.7 times higher in the liver during treatment and on the first day post treatment this correlation decreased 2.5 times. These results point on intensive metabolism of enrofloxacin in the liver during treatment. The drug was gradually eliminated from the chicken's body. Enrofloxacin is metabolised in the liver and transformed into the main metabolite ciprofloxacin and some minor metabolites such as: oxociprofloxacin, enrofloxacin amide, dioxociprofloxacin, desethylene ciprofloxacin, destethylene enrofloxacin, $\mathrm{N}$-formyl ciprofloxacin, oxoenrofloxacin and hydroxy oxoenrofloxacin (EMEA, 1998; Prescott et al., 2000). The level of enrofloxacin transformation to ciprofloxacin is not so high. We have found that most of the residue in the liver and muscles at the end of treatment was enrofloxacin.

Anadon et al. (1995) treated chickens with enrofloxacin $10 \mathrm{mg} / \mathrm{kg} / \mathrm{day}$ for four days, on the fifth day they have determined $540 \mathrm{ng} / \mathrm{g}$ enrofloxacin and $650 \mathrm{ng} / \mathrm{g}$ ciprofloxacin in the meat and $990 \mathrm{ng} / \mathrm{g}$ enrofloxacin and $960 \mathrm{ng} / \mathrm{g}$ ciprofloxacin in the liver. These authors concluded that ciprofloxacin level is always similar or greater than enrofloxacin level. In our experiment we found lower levels of ciprofloxacin in the liver and significantly lower in the breast muscle. Our findings are similar to the findings of Schneider (2001). She treated chickens with enrofloxacin $11 \mathrm{mg} / \mathrm{kg} /$ day for seven days and found 2-10 times lower levels of ciprofloxacin in the meat and liver. Knoll et al. (1999) reported that ciprofloxacin concentrations in chicken's organs were about $4 \%$ of enrofloxacin concentrations, eccept in the liver $38 \%$ and kidney $11 \%$. Our results are close to the data published by EMEA report (1998): $85 \%$ residue in chicken meat and $66 \%$ in chicken liver is enrofloxacin.

Results of the screening method are manifested by the presence of the inhibition zone, that is proportional to the quantity of antibiotics in the sample. Therefore, results of the screening method are not only qualitative but also semiquantitative. Statistical data processing of the inhibition zone width showed that there are significant differences in the inhibition zone width between the samples taken at different times of the chicken's life - cycle (Tables 3-4). Twenty four hours after the beginning of therapy until the first day after the end of therapy, inhibition width expressed a constant and significant $(p<0.05)$ increase. Also, the screening method discovered a significantly $(p<0.05)$ higher quantity of residues in the liver, and meat. These results were proved by HPLC method (Table 5). The screening method was used to examine individual samples of meat and liver in every sacrificed chicken. The variation interval showed in the results $(0.806-1.349 \mathrm{~mm})$ is a consequence of great variation in the quantity of residues in some chickens. Anadon et al. (1995) after treatment of chickens with enrofloxacin, discovered that individual differences can be great; $110 \mathrm{ng} / \mathrm{g}$ enrofloxacin or even $670 \mathrm{ng} / \mathrm{g}$ of ciprofloxacin in the liver. It may be assumed that these variations are a consequence of uneven intake of water, which results in an uneven intake of the drug.

The inhibition zone width has a significant $(p<0.05)$ increase compared to the measurements at the beginning of therapy, and all the meat and liver samples had a positive response. From the second day of the withdrawal period in muscle 
samples the inhibition zones were significantly $(p<0.05)$ reduced. On the fourth day of the withdrawal period only $16.67 \%$ of muscle samples had a positive response.

The presence of residues in the liver was determined up to the third day after the withdrawal period with a significant $(p<0.05)$ decrease of inhibition zones. However, there was a $100 \%$ positive response.

Two days after the end of the withdrawal period enrofloxacin was detected by HPLC method in meat $(24.8 \mathrm{ng} / \mathrm{g})$ and in liver $(45.2 \mathrm{ng} / \mathrm{g})$, while ciprofloxacin was not detected. Similar results were discovered by Schneider (2001) and only three days after the end of therapy there was $38.2 \mathrm{ng} / \mathrm{g}$ of enrofloxacin and $0.97 \mathrm{ng} / \mathrm{g}$ ciprofloxacin in the meat, but in the liver there was $142.0 \mathrm{ng} / \mathrm{g}$ of enrofloxacin and $51.0 \mathrm{ng} / \mathrm{g}$ of ciprofloxacin. Recent data from the same author, with a supplied lower dose of enrofloxacin $(50 \mu \mathrm{g} / \mathrm{ml})$ for the same period, are as follows: in the meat there were $28.8 \mathrm{ng} / \mathrm{g}$ enrofloxacin and $0.00 \mathrm{ng} / \mathrm{g}$ of ciprofloxacin, and in the liver $70.8 \mathrm{ng} / \mathrm{g}$ of enrofloxacin and $25.1 \mathrm{ng} / \mathrm{g}$ of ciprofloxacin (Schneider and Donoghue, 2002). In EMEA (1998) reports three days after the withdrawal period $42 \mathrm{ng} / \mathrm{g}$ of enrofloxacin were found in chicken liver.

Residues could not be detected using HPLC 15 days after the withdrawal period. Similar data are found in the reports of EMEA (1998) where 15 days after the end of therapy an extremely low quantity of residues was measured in the liver (11 $\mathrm{ng} / \mathrm{g}$ of enrofloxacin).

\section{CONCLUSIONS}

1. After oral therapy with ernofloxacin, residue levels are 2-4 times higher in the liver than in meat. Residues mostly consist of enrofloxacin and a smaller quantity of ciprofloxacin.

2. Four days withdrawal period allowed time for the drug concentration, in both meat and liver, to decrease to an acceptable level prior to slaughter (below EU MRL for enrofloxacin and ciprofloxacin).

3 . The results of examining the residues in tissues in treated animals using screening method on Plate $\mathrm{pH} 8 \mathrm{E}$ coli NCIMB 11595 entirely fulfill the demands of a qualitative method. Examination of tissue samples of treated animals by the screening method gave positive results in all the samples where the residue content was above MRL level.

Address for correspondence:

Mr. Jelena Petrović,

Scientific Veterinary Institute "Novi Sad",

Rumenački put 20

21000 Novi Sad, Serbia

e-mail: jelenap@niv.ns.ac.yu 


\section{REFERENCES}

1. Anadon A, Martinez-Larranaga MR, Diaz MJ, Velez C, Bringas $P$, 1990, Pharmacokinetiks and residue studies of quinolone compounds and olaquindox in poultry, Ann Rech Vet, 1, 137-44.

2. Anadon A, Martinez-Larranaga MR, Diaz MJ, Bringas P, Martinez MA, Fernandez-Cruz ML et al., 1995, Pharmacokinetics and residues of enrofloxacin in chickens, Am J Vet Ress, 56, 4, 501-6.

3. Cerniglia CE, Kotarski S, 1999, Evaluation of veterinary drug residues in food for their potential to affect human intestinal microflora, Regulatory Toxicology and Pharmacology, 29, 238-61.

4. Consleg system of the Office for Official Publications of the European Communities, 2002, Consolidated text, Consleg, R1181-05/07/2002, 1-11.

5. EMEA, Comittee for veterinary medicinal products, 1998, Enrofloxacin. Summary report (2), EMEA/MRL/388/98-FINAL, 1-6.

6. Hadžić O, 1992, Disperziona analiza, U: Hadžić O, urednik, Numeričke i statističke metode u obradi eksperimentalnih podatatka, Drugo izdanje, Novi Sad: Univerzitet u Novom Sadu, Institut za matematiku, Štamparija za graf. delatnost, 194-06.

7. Ho DY, Song JC, Wang CC, 2003, Anaphylactoid reaction to ciprofloxacin, Ann Pharmacother, 37, 7, 1018-23.

8. Jezdimirović MB, 2002, Hinoloni (Kvinoloni), U: Jezdimirović MB, urednik, Osnovi farmakoterapije $i$ gotovo lekovi ad us. vet., Beograd: Fakultet veterinarske medicine, Beograd, AD štamparija "Kultura" Bački Petrovac, 197-9.

9. Klecak G, Urbach F, Urwyler H, 1997, Fluoroquinolone antibacterials enchance UVA-induced skin tumors, J Photochem Photobiol B: Biology, 37, 174-81.

10. Knoll U, Glunder G, Kietzmann M, 1999, Comparative study of the plasma pharmacokinetics and tissue concentrations of danofloxacin and enrofloxacin in broiler chickens, $J$ vet Pharmacol Therap, 22, 239-46.

11. Less P, Aliabadi FS, 2002, Rational dosing of antimicrobial drugs: animal versus humans, Int $J$ of Antimicrobial Agents, 19, 269-84.

12. Martindale, 2005, In: Sweetman S, editor, The Complete Drug Reference, Thirty fourth edition, London: Pharmaceutical Press.

13. Martinez M, McDermott $P$, Walker R, 2005, Pharmacology of the fluoroquinolones: a perspective for the use in domestic animals, The Vet Journal, in press.

14. Pierfitte C, Gillet P, Royer R, 1995, More on fluoroquinolone antibiotics and tendon rupture, $N$ Engl J Med, corespondence, 332:193, 3, 414-6.

15. Prescott JF, Baggot JD, Walker RD, 2000, Fluoroquinolones, In: Prescott JF, Baggot JD, Walker RD, editors, Antimicrobial therapy in veterinary medicine, Third Edition, Ames: lowa State University Press, 315-39.

16. Ramos M, Aranda A, Garcia E, Reuvers T, Hooghuis H, 2003, Simple and sensitive determination of five quinolones in food by liquid chromatography with fluorescence detection, $J$ of Chromatography $B, 789,2,373-81$.

17. Report and Proceedings of a WHO Meeting, 1998, Quinolone use in animals and resistance in animal bacteria. Use of quinolones in food animals and potential impact on human health, Geneva, Switzerland, 2-5 June, 9-13.

18. Schneider MJ, 2001, Multiresidue analysis of fluoroquinolone antibiotics in chicken tissue using automated microdialysis-liquid chromatography, J of Chromatographic Sci, 39, 351-6.

19. Schneider MJ, Donoghue DJ, 2002, Multiresidue analysis of fluoroquinolone antibiotics in chicken tissue using liquid chromatography-fluorescence-multiple mass spectrometry, J Chromatogr $B, 780,1,83-92$.

20. Stahlman R, Kuhner S, Shakibaei M, SchwabeR, Flores J, Evander SA et al., 2000, Chondrotoxicity of ciprofloxacin in immature beagle dogs: Immunohistochemistry, electron microscopy and drug plasma concentrations, Arch Tochicol, 73, 10-11, 564-72.

21. Ćupić V, Dobrić S, Trailović D, Pejčić Z, 2004, Antimicrobial drugs in veterinary medicine, Veterinarski glasnik, 58, 5-6, 577-94. 


\section{REZIDUE ENROFLOKSACINA I NJEGOVOG GLAVNOG METABOLITA CIPROFLOKSACINA KOD BROJLERA}

PETROVIĆ JELENA, BALTIĆ M, ĆUPIĆ V, STEFANOVIĆ S i STOJANOVIĆ DRAGICA

\section{SADRŽAJ}

Prisustvo rezidua enrofloksacina u mesu i jetri pilića ispitivano je posle peroralnog aplikovanja enrofloksacina $(10 \mathrm{mg} / \mathrm{kg}$ t.m./dan. Za ispitivanje rezidua su korišćene: mikrobiološka metoda - ploča pH 8.0 sa Escherichia coli NCIMB 11595 i HPLC metoda sa fluorescentnom detekcijom. Tokom pet dana primene terapije, koncentracije enrofloksacina u grudnoj muskulaturi i jetri su bile značajno iznad EU maksimalno dozvoljenih koncentracija (MDK). Ciprofloksacin nije detektovan u muskulaturi drugog dana primene terapije ali je detektovan u jetri u koncentracijama iznad MDK. Posle prekida terapije, koncentracije enrofloksacina i ciprofloksacina u grudnoj muskulaturi i jetri su bile iznad MDK nivoa do četvrtog dana karence. Ciprofloksacin nije detektovan u muskulaturi četvrtog dana karence ali je detektovan u jetri u koncentracijama ispod MDK. Četiri dana karence su period koji omogućuje da koncentracija leka u mesu i jetri padne na prihvatljiv nivo pre klanja (ispod MDK). Mikrobiološka metoda - ploča pH 8.0 sa Escherichia coli NCIMB 11595 daje pozitivne rezultate u svim uzorcima u kojima je sadržaj rezidua bio iznad MDK. 